\title{
PEMETAAN KOMPETENSI TEKNOLOGI INFORMASI DAN KOMUNIKASI (TIK) GURU PADA DIMENSI PEDAGOGIK
}

\author{
An An Herliani dan Dinn Wahyudin \\ Pengembangan Kurikulum, SPs Universitas Pendidikan Indonesia \\ e-mail: anherliani@ student.upi.edu
}

\begin{abstract}
Abstrak
Kompetensi TIK diharapkan dapat menjadi penopang bagi peningkatan kompetensi pedagogik dan profesional bagi seorang guru. Kajian ini bertujuan untuk mengembangkan kompetensi TIK guru pada dimensi pedagogik yang dapat dijadikan rujukan dalam perancangan program peningkatan kompetensi guru oleh lembaga penyelenggara pendidikan dan pelatihan. Melalui pendekatan Penelitian Desain dan Pengembangan (Design and Development Research) dengan merujuk pada kerangka kerja kompetensi TIK untuk guru yang dikembangkan oleh UNESCO (UNESCO ICT Competency Framework for Teachers). Hasil penelitian telah memetakan kompetensi TIK yang dapat dicapai oleh guru melalui Pengembangan Keprofesian Berkelanjutan secara berjenjang dalam tiga level kompetensi yang dilengkapi dengan deskripsi kompetensi pada setiap levelnya.
\end{abstract}

Kata Kunci: kompetensi guru, Diklat, Pengembangan Keprofesian Berkelanjutan (PKB), Kerangka Kerja Kompetensi TIK

\section{MAPPING INFORMATION AND COMMUNICATION TECHNOLOGY (ICT) COMPETENCY FOR TEACHERS FROM THE PEDAGOGIC DIMENSION}

\begin{abstract}
ICT competence is expected to be a support for the improvement of pedagogical and professional competence for a teacher. This study aims to develop teacher's ICT competence on the pedagogic dimension that can be used as a reference in the design of teacher competency improvement programs by education and training providers. Through the Design and Development Research approach by referring to the ICT competency framework for teachers developed by UNESCO. The research results have mapped the competence of ICT that can be achieved by teachers through Continuous Professional Development in three levels of competence with a description of competence at each level.
\end{abstract}

Keywords: teachers competency, Teacher Development Program, Continuous Professional Development, ICT Competency Framework.

\section{PENDAHULUAN}

Guru merupakan salah satu komponen utama dalam sistem pendidikan nasional yang memiliki posisi strategis dalam mewujudkan tujuan pendidikan nasional, yakni mencerdaskan kehidupan bangsa dan mengembangkan manusia Indonesia seutuhnya. Peran guru dalam pelaksanaan pendidikan diperkuat dengan pencanangan guru sebagai profesi oleh Presiden Republik Indonesia pada puncak peringatan Hari Guru Nasional XII tanggal 2 Desember 2004 (Kemendikbud, 2015a).
Demikian halnya dalam Undang-Undang Nomor 14 tahun 2005 tentang Guru dan Dosen Pasal 1 ayat 3 menyatakan bahwa guru adalah pendidik profesional dengan tugas utama mendidik, mengajar, membimbing, mengarahkan, melatih, menilai, dan mengevaluasi peserta didik pada pendidikan anak usia dini jalur pendidikan formal, pendidikan dasar, dan pendidikan menengah (UU Nomor 14, 2005). Sebagai tenaga profesional, guru harus memiliki kualifikasi akademik dan kompetensi sebagai agen pembelajaran, sehat jasmani 
dan rohani, serta memiliki kemampuan untuk mewujudkan tujuan pendidikan nasional (Mulyasa, 2013).

Tugas guru sebagai suatu profesi, menuntut kepada guru untuk mengembangkan profesionalitas diri sesuai perkembangan ilmu pengetahuan dan teknologi. Mendidik, mengajar, dan melatih anak didik adalah tugas guru sebagai suatu profesi. Tugas guru sebagai pendidik berarti meneruskan dan mengembangkan nilai-nilai hidup kepada anak didik. Tugas guru sebagai pengajar berarti meneruskan dan mengembangkan ilmu pengetahuan dan teknologi kepada anak didik. Tugas guru sebagai pelatih berarti mengembang-kan keterampilan dan menerapakannya dalam kehidupan demi masa depan anak didik (Kristiawan, 2017).

Karier guru profesional sepatutnya dipahami sebagai sebuah proses berkesinambungan, berlangsung lama, dan perlu pembinaan yang berkelanjutan (Wahyudin, 2016 dan Wahyudin, 2017). Selain berdasarkan inisiatif guru untuk terus mengupdate ilmu pengetahuan dan kompetensinya, dalam hal ini pemerintah pusat dan daerah mempunyai kewajiban dalam proses pembinaan guru. Undang-undang Republik Indonesia Nomor 14 Tahun 2005 tentang Guru dan Dosen secara eksplisit mengamanatkan adanya pembinaan dan pengembangan profesi guru secara berkelanjutan sebagai aktualisasi dari sebuah profesi pendidik. Pengembangan Keprofesian Berkelanjutan dilaksanakan bagi semua guru, baik yang sudah bersertifikat maupun belum bersertifikat (Kemendikbud, 2017).

Berkaitan dengan program tersebut, pemetaan kompetensi yang secara detail menggambarkan kondisi objektif guru dan merupakan informasi penting bagi pemerintah dalam mengambil kebijakan terkait dengan materi dan strategi pembinaan yang dibutuhkan oleh guru. Peta guru tersebut dapat diperoleh melalui Uji Kompetensi Guru (UKG). Sasaran program strategi pencapaian target RPJMN tahun 2015-2019 antara lain adalah meningkatnya kompetensi guru dan tenaga kependidikan dilihat dari Subject Knowledge dan Pedagogical Knowledge yang diharapkan akan berdampak pada kualitas hasil belajar siswa (Kemendikbud, 2015b).

Pada tahun 2015 sebanyak 2.699.516 orang guru (Kemdikbud, 2017) telah mengikuti UKG dengan hasil rata-rata nasional untuk kompetensi bidang pedagogik dan profesional adalah 53,02. Terdapat tiga provinsi yang mendapatkan nilai di atas rata-rata nasional, diantaranya Kepulauan Riau (54.72), Sumatera barat (54.68), dan Kalimantan Selatan (53.15). Menurut Direktur Jenderal Guru dan Tenaga Kependidikan (GTK) Kemendikbud pada saat itu, Sumarna Surapranata, jika dirinci lagi untuk hasil UKG pada kompetensi bidang pedagogik saja rata-rata nasionalnya hanya 48,94, berada di bawah Standar Kompetensi Minimal (SKM) yaitu 55. Bahkan untuk bidang pedagogik ini hanya ada satu provinsi yang nilainya di atas rata-rata nasional sekaligus mencapai SKM yaitu DI Yogyakarta $(56,91)$ (Maulipaksi, 2016). Artinya, seca-ra umum guru sangat memerlukan peningkatan kompetensi pedagogik dan kompetensi profesional untuk dapat mencapai standar yang telah ditetapkan.

Sebagai tindak lanjut UKG, Direktorat Jenderal Guru dan Tenaga Kependidikan telah menyelenggarakan Program Peningkatan Kompetensi Guru Pembelajar pada tahun 2015 - 2016, kemudian menjadi Program Pengembangan Keprofesian Berkelanjutan (PKB) pada tahun 2017. Program PKB bertujuan untuk meningkatkan kompetensi guru yang dirancang berdasarkan Standar Kompetensi Guru (SKG) yang mengacu pada Permendiknas Nomor 16 Tahun 2007 tentang Standar Kualifikasi Akademik dan Kompetensi Guru, Permendiknas Nomor 27 Tahun 2008 tentang Standar Kualifikasi Akademik dan Kompetensi Konselor, Permendiknas Nomor 32 Tahun 2008 tentang Standar Kualifikasi Akademik dan Kompetensi Guru Pendidikan Khusus, dan Permendikbud Nomor 137 Tahun 2014 tentang Standar Nasional Pendidikan Anak 
Usia Dini. Berdasarkan Indikator Pencapaian Kompetensi (IPK) dalam SKG dikembangkan peta kompetensi guru yang dibagi menjadi 10 (sepuluh) kelompok kompetensi, selanjutnya dikembangkan juga modul. Secara teknis pengembangan kelompok kompetensi dan modul tersebut dilaksanakan oleh PPPPTK sesuai dengan bidang masing-masing (Kemdikbud, 2017).

Didukung oleh pola pendidikan pada Abad 21 dimana pendidikan dituntut untuk menjamin peserta didik memiliki keterampilan belajar dan berinovasi, keterampilan menggunakan teknologi dan media informasi, serta dapat bekerja dan bertahan dengan menggunakan keterampilan untuk hidup (life skills) (Murti, 2015). Guru dituntut untuk menciptakan pembelajaran yang kreatif dan inovatif dengan mengintegrasikan Teknologi Informasi dan Komunikasi (TIK) ke dalam kegiatan pembelajaran untuk membekali siswa dalam mengembangkan dirinya sebagai pembelajar sepanjang hayat dengan memiliki keterampilan literasi informasi, literasi media dan literasi TIK.

Kewajiban memanfaatan TIK untuk kepentingan pembelajaran, terkait dengan Kompetensi Inti Guru dalam ranah Kompetensi Pedagogik, sedangkan memanfaatkan TIK untuk mengembangkan diri terkait dengan Kompetensi Inti Guru dalam ranah Kompetensi Profesional sebagaimana yang tercantum dalam Permendiknas Nomor 16 tahun 2007 tentang Standar Kualifikasi Akademik dan Kompetensi Guru. Pernyataan ini dapat diartikan bahwa kompetensi TIK diharapkan dapat menjadi penopang bagi peningkatan kompetensi pedagogik dan profesional bagi seorang guru. Kepentingan guru memiliki kompetensi TIK adalah untuk mengintegrasikan TIK dalam kegiatan pembelajaran dan mengembangkan diri dalam kegiatan profesionalnya, namun kehadiran TIK tidak serta merta membawa guru memiliki kompetensi TIK, faktanya meskipun ketersedian perangkat TIK untuk pendidikan meningkat tetapi tidak berbanding lurus dengan penggunaannya dalam kegiatan pembe- lajaran. Guru bisa jadi seorang pengguna teknologi terampil, tetapi tidak dapat mengambil manfaat dan menerapkannya dalam pengajaran di lembaga pendidikan. Guru berpikir bahwa penggunaan teknologi tidak mendukung proses belajar dan mengajar, meskipun perangkat TIK tersedia di lembaga pendidikan. Selain itu, guru tidak berpengalaman dalam menggu-nakan TIK secara efektif dalam kegiatan kelas secara reguler maupun di luar kelas (Rajsekhar, 2013).

Berdasarkan uraian tersebut, maka urgensi peningkatan kompetensi guru yang berkaitan dengan pemanfaatan TIK menjadi suatu kebutuhan mendesak untuk menjadi seorang guru profesional di abad 21 . Diperlukan suatu deskripsi utuh mengenai kompetensi TIK yang harus dimiliki seorang guru, agar dapat disesuaikan dengan desain program peningkatan kompetensi guru oleh vendor diklat, dalam hal ini PPPPTK yang bertanggungjawab dalam peningkatan kompetensi Pendidik dan Tenaga Kependidikan (PTK). Untuk menunjang program tersebut, penelitian ini bermaksud untuk memetakan dan mendeskripsikan kompetensi TIK guru pada dimensi pedagogik untuk dapat dijadikan rujukan dalam perancangan program peningkatan kompetensi guru oleh lembaga penye-lenggara pendidikan dan pelatihan pada Program Pengembangan Keprofesian Berkelanjutan (PKB).

\section{METODE}

Metodologi penelitian ini menggunakan pendekatan Penelitian Desain dan Pengembangan (Design and Development Research). Richey \& Klein (2007) mendefinisikan Design and Development Research sebagai

the systemic study of design, development amd evaluation processes with the aim of establishing an empirical basic for the creation of instructional and non-instructional products and tools and new or enhance models that govern their development. (Richey \& Klein, 2007). 
Mengacu pada definisi tersebut, terdapat beberapa poin yang dapat disimpulkan: a) Design and Development Research adalah studi sistematis yang meliputi desain, pengembangan dan evaluasi. Artinya, penelitian ini sama dengan studi lainnya yang harus dirancang dan dilaksanakan dengan baik. b) Tujuannya adalah untuk menciptakan produk, alat (tool), dan model yang bersifat instruksional maupun non-instruksional.

Desain penelitian dikembangkan dalam 4 (empat) tahapan yakni Analisis, Desain, Pengembangan, dan Implementasi. (Richey \& Klein, 2007).

1. Tahap Analisis

Menganalisa kebutuhan dan konteks, kajian pustaka, dan mengembangkan kerangka teoretis. Akker (1999) menyebutnya sebagai analisis pendahuluan (preliminary investigation). Pemeriksaan pendahuluan yang sistematis dan intensif dari permasalahan yang ada antara lain mencakup beberapa hal sebagai berikut: (a) tinjauan ulang literatur, (b) konsultasi tenaga ahli, (c) analisa tentang ketersediaan contoh untuk tujuan yang terkait, dan (d) studi kasus dari praktek yang umum untuk merincikan kebutuhan.

Pada tahap ini peneliti melakukan analisis terhadap rancangan diklat TIK yang dikembangkan di PPPPTK Pertanian, serta modul diklat Pemanfaatan TIK pada Kompetensi Pedagogik. Analisis difokuskan pada ruang lingkup konten atau materi modul. Selanjutnya dilakukan kajian regulasi yang berkaitan dengan kompetensi guru, kajian literatur mengenai kerangka kompetensi TIK guru khususnya dari dimensi pedagogik, serta konsultasi pakar.

2. Tahap Desain

Pada tahap ini dilakukan desain pemetaan kompetensi TIK guru sebagai hasil studi pendahuluan, yang menyatakan level kompetensi TIK yang harus dicapai guru. Setiap level dilengkapi dengan deskripsi kompetensi pada dimensi pedagogik.

3. Tahap Pengembangan

Hasil desain pemetaan kompetensi TIK guru selanjutnya dilakukan tinjaun pakat (expert review) pada Tahap Pengembangan. Tujuan penilaian pakar adalah untuk memvalidasi rancangan pemetaan kompetensi TIK guru dan deskripsi pada setiap level kompetensi. Pakar terdiri dari kalangan akademisi (Dosen), praktisis pendidikan, dalam hal ini widyaiswara yang sesuai dengan bidangnya, serta guru sebagai user. Saran-saran para pakar digunakan untuk penyempurnaan pemetaan dan deskripsi kompetensi TIK.

4. Tahap Implementasi

Hasil pemetaan kompetensi TIK guru yang dilengkapi dengan deskripsi pada setiap level kompetensi selanjutnya dapat digunakan sebagai rujukan pada rancangan pendidikan dan pelatihan oleh vendor yang bertugas dalam pengembangan dan peningkatan kompetensi guru, khususnya PPPPTK.

Dalam penelitian ini, tahap implementasi tidak menjadi bagian dari penelitian karena keterbatasan waktu dan memerlukan prosedur panjang untuk implementasi di lapangan terkait dengan kebijakan pelaksanaan diklat oleh lembaga yang berkepentingan.

Secara ringkas desain metodologi penelitian digambarkan sebagai berikut.
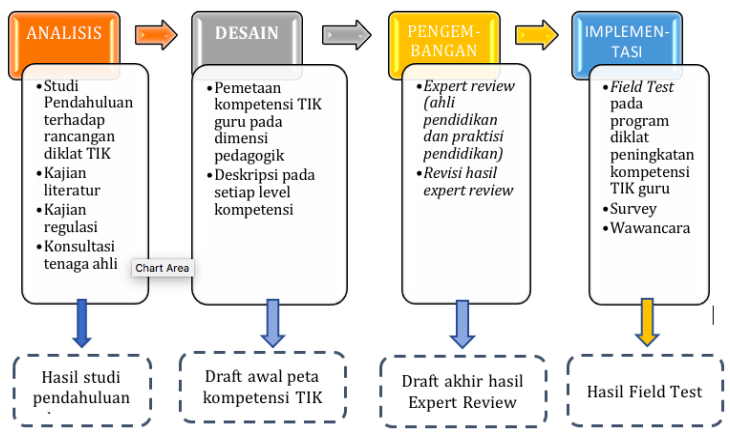

Gambar 1. Desain metodologi penelitian

\section{HASIL DAN PEMBAHASAN \\ Hasil}

Hasil penelitian ini merupakan studi pendahuluan dari penelitian yang masih 
berlangsung. Kajian literatur, kajian regulasi, dan konsultasi informal dengan tenaga ahli menjadi pijakan dalam pengumpulan data studi pendahuluan. Hasil penelusuran studi pendahuluan menghasilkan desain awal Pemetaan Kompetensi TIK guru pada dimensi pedagogik. Pemetaan kompetensi TIK ini dikembangkan lebih lanjut menjadi deskripsi kompetensi yang harus dicapai guru pada setiap levelnya.

Tahap berikutnya, masih diperlukan penilaian ahli (expert judgment) yang berguna dalam memvalidasi kesesuaian hasil pemetaan kompetensi dan deskripsi kompetensi sebelum diimplementasikan sebagai rujukan dalam perancangan diklat peningkatan kompetensi TIK guru.

Merujuk pada hasil analisis dari kajian literatur, diantaranya Standar dan kompetensi TIK ditinjau dari dimensi pedagogik dikembangkan oleh UNESCO melalui dokumen yang bertajuk ICT
Standars and Competencies from The Pedagogical Dimension: A Perspektive from Levels of ICT Adoption in Teachers' Education Practice, dan frame kompetensi TIK untuk guru yang juga dikembangkan oleh UNESCO (UNESCO ICT Compeetnsy Framework for Teachers), serta beberapa referensi lain yang relevan.

Diperoleh rumusan bahwa kompetensi TIK guru dapat dipetakan ke dalam 3 (tiga) tingkat/level kemampuan, yaitu (1) Literasi Teknologi (Technology Literacy); (2) Pendalaman Pengetahuan (Knowledge Deepening); dan (3) Kreasi Pengetahuan (Knowledge Creation). Di mana setiap level kemampuan TIK harus mengembangkan serangkaian kompetensi dalam penggunaan teknologi dengan memprioritaskan keterampilan pada ranah pedagogik yang mencakup ruang lingkup Desain, Implementasi, dan Evaluasi. Hasil pemetaan kompetensi tersebut dipetakan pada tabel berikut.

Tabel 1. Pemetaan kompetensi TIK

\begin{tabular}{|c|c|c|c|}
\hline \multirow[t]{2}{*}{ KOMPONEN } & \multicolumn{3}{|c|}{ KOMPETENSI TIK } \\
\hline & $\begin{array}{l}\text { TECHNOLOGY } \\
\text { LITERACY }\end{array}$ & KNOWLEDGE DEEPENING & $\begin{array}{l}\text { KNOWLEDGE } \\
\text { CREATION }\end{array}$ \\
\hline $\begin{array}{l}\text { KOMPETENSI } \\
\text { PADA } \\
\text { DIMENSI } \\
\text { PEDAGOGIK }\end{array}$ & \multicolumn{3}{|c|}{$\begin{array}{l}\text { 1. DESAIN : keterampilan guru dalam merancang dan mengatur semua elemen } \\
\text { yang mengarah pada konstruksi pendidikan yang diaktifkan dengan TIK } \\
\text { untuk pembelajaran bermakna dan pendidikan komprehensif bagi siswa } \\
\text { 2. IMPLEMENTASI : keterampilan guru dalam memfasilitasi dan } \\
\text { menerapkan perancangan dan perencanaan pendidikan yang direfleksikan } \\
\text { dalam praktik pembelajaran } \\
\text { 3. EVALUASI : kemampuan guru dalam mengevaluasi efektifitas } \\
\text { pembelajaran yang diintegrasikan dengan TIK untuk meningkatkan } \\
\text { pembelajaran siswa yang bermakna. }\end{array}$} \\
\hline & Mengintegrasikan & Pemecahan Masalah yang & Manajemen Diri (Self \\
\hline KURIKULUM & $\begin{array}{l}\frac{\text { Teknologi }}{(\text { Integrate }} \\
\frac{\text { Technology })}{\text { Mengintegrasikan }} \\
\text { teknologi, peralatan } \\
(\text { tools }) \text {, dan konten } \\
\text { digital ke dalam } \\
\text { praktik pedagogi di } \\
\text { kelas, kelompok dan } \\
\text { kegiatan individu } \\
\text { siswa untuk } \\
\text { mendukung } \\
\text { pembelajaran. }\end{array}$ & $\begin{array}{l}\text { Kompleks } \\
\text { Problem Solving) } \\
\text { Menerapkan pendekatan } \\
\text { pembelajaran berbasis proyek } \\
\text { dan berbasis masalah } \\
\text { kolaboratif (collaborative } \\
\text { problem) dimana siswa } \\
\text { mengeksplorasi subjek secara } \\
\text { mendalam dan menggunakan } \\
\text { pengetahuan mereka untuk } \\
\text { menyelesaikan masalah } \\
\text { kompleks, isu-isu, dan } \\
\text { pertanyaan sehari-hari } \\
\text { dengan mengoptimalkan TIK. }\end{array}$ & $\begin{array}{lr}\text { Management) } \\
\text { Siswa bekerja dalam } \\
\text { komunitas belajar untuk } \\
\text { menciptakan produk- } \\
\text { produk yang dibangun dari } \\
\text { pengetahuan r dan } \\
\text { keterampilan mereka } \\
\text { sendiri. }\end{array}$ \\
\hline
\end{tabular}




\begin{tabular}{|c|c|c|c|}
\hline \multirow[t]{2}{*}{ KOMPONEN } & \multicolumn{3}{|c|}{ KOMPETENSI TIK } \\
\hline & $\begin{array}{l}\text { TECHNOLOGY } \\
\text { LITERACY }\end{array}$ & KNOWLEDGE DEEPENING & $\begin{array}{l}\text { KNOWLEDGE } \\
\text { CREATION }\end{array}$ \\
\hline $\begin{array}{l}\text { KOMPETENSI } \\
\text { GURU }\end{array}$ & $\begin{array}{l}\text { Guru harus tahu di } \\
\text { mana, dengan siapa, } \\
\text { kapan (serta kapan } \\
\text { tidak) dan } \\
\text { bagaimana } \\
\text { menggunakan TIK } \\
\text { untuk kegiatan } \\
\text { pembelajaran dan } \\
\text { presentasi. }\end{array}$ & $\begin{array}{l}\text { Mengajar dalam pendekatan } \\
\text { ini berpusat pada siswa. Peran } \\
\text { guru adalah untuk } \\
\text { memberikan tugas-tugas } \\
\text { secara terstruktur, } \\
\text { membimbing siswa agar } \\
\text { memahami, dan mendukung } \\
\text { siswa dalam proyek } \\
\text { kolaboratif. Guru harus } \\
\text { mempunyai keterampilan } \\
\text { untuk membantu siswa dalam } \\
\text { menciptakan, menerapkan, } \\
\text { memantau, dan memberikan } \\
\text { solusi dalam rencana proyek } \\
\text { mereka. }\end{array}$ & $\begin{array}{lr}\text { Peran guru } & \text { dalam } \\
\text { pendekatan ini adalah } \\
\text { secara } & \text { eksplisit } \\
\text { memodelkan proses } \\
\text { belajar dan menciptakan } \\
\text { situasi di mana siswa } \\
\text { menerapkan keterampilan } \\
\text { kognitif dan membimbing } \\
\text { mereka dalam mencapai } \\
\text { kemahiran. ran } \\
\text { Guru juga berkolaborasi } \\
\text { dengan rekan kerja dalam } \\
\text { menerapkan retting } \\
\text { pendidikan rang } \\
\text { diaktifkan dengan TIK. }\end{array}$ \\
\hline
\end{tabular}

Selanjutnya, untuk pengembangan diklat peningkatan kompetensi TIK guru oleh vendor diklat (PPPPTK), ditawarkan model diklat berdasarkan tingkat adopsi TIK dan penggunaannya dalam proses pendidikan di sekolah dengan mempertimbangkan aspek pengembangan kompetensi TIK dari perspektif pedagogis, didaktik, reflektif dan kritis seputar peran yang dimainkan teknologi dalam membangun pengetahuan dan pengembangan sosial.

Tingkat adopsi yang dimaksud terbagi kedalam tiga tingkatan, yaitu: (1) memperkenalkan (familiarize); (2) memanfaatkan (utilize); dan (3) mengubah (transform). Familiarize mengacu pada apa yang guru ketahui tentang teknologi dan penggunaannya (pengetahuan deklaratif). Utilize mengacu pada penggunaan praktik pendidikan sehari-hari yang melibatkan adopsi TIK (dengan kecenderungan prosedural). Terakhir, Transform berhubungan dengan perubahan adaptif terhadap praktik yang melibatkan penggunaan teknologi di kelas.

Tiga level kompetensi pada ranah pedagogik dengan mengadopsi model diklat dengan menerapkan elemen kompetensi pada tingkatan Familiarize, Utilize, dan Transform, menghasilkan rumusan deskripsi kompetensi yang disajikan dalam tabel berikut. 
1. Level Literasi Teknologi (Technology Literacy)

\begin{tabular}{|c|c|c|c|}
\hline $\begin{array}{c}\text { Ruang } \\
\text { Lingkup }\end{array}$ & Familiarize & Utilize & Transform \\
\hline Desain & 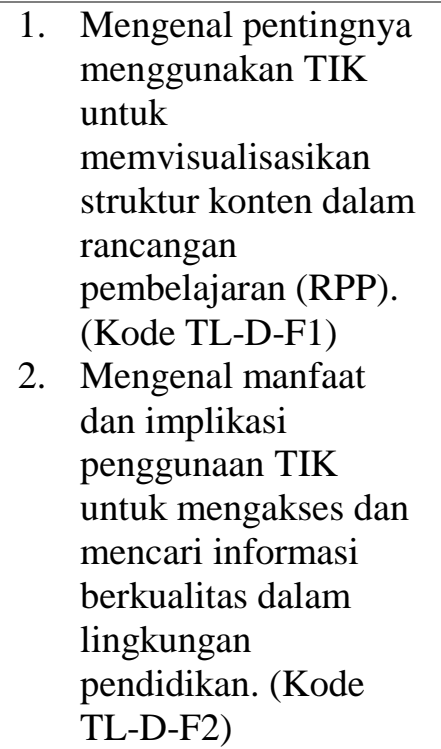 & 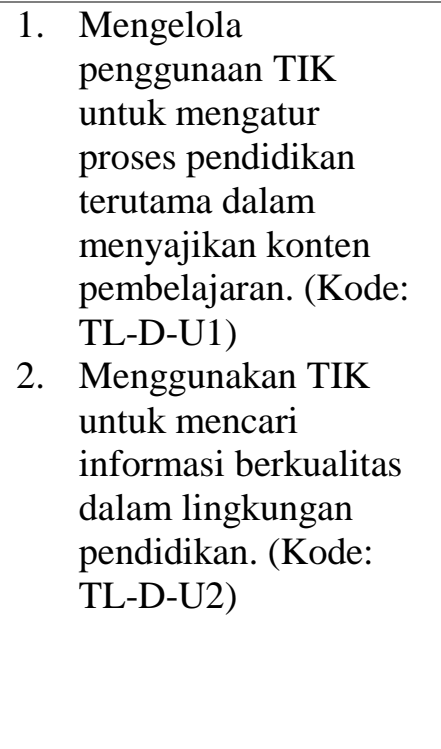 & $\begin{array}{l}\text { Menambah, } \\
\text { menghapus dan/atau } \\
\text { mereorganisasi alat } \\
\text { TIK untuk } \\
\text { melengkapi konten, } \\
\text { presentasi; } \\
\text { penyimpanan, } \\
\text { komunikasi, } \\
\text { transmisi dan } \\
\text { pertukaran informasi } \\
\text { dalam mencari } \\
\text { informasi berkualitas. } \\
\text { (Kode: TL-D-T1) }\end{array}$ \\
\hline Implementasi & $\begin{array}{l}\text { Mengenal fungsi alat TIK } \\
\text { untuk mengelola akses dan } \\
\text { pencarian informasi } \\
\text { berkualitas (Kode TL-I-F1) }\end{array}$ & $\begin{array}{ll}\text { 1. } & \text { Menggunakan TIK } \\
\text { secara efektif dalam } \\
\text { komunikasi dan } \\
\text { transmisi konten serta } \\
\text { aktivitas dengan siswa } \\
\text { dan antar siswa. } \\
\text { (Kode TL-I-U1) } \\
\text { 2. } \text { Menggunakan TIK } \\
\text { untuk } \\
\text { mendeskripsikan, } \\
\text { mengatur dan } \\
\text { menginformasikan } \\
\text { tentang kegiatan yang } \\
\text { akan dilakukan di } \\
\text { lingkungan } \\
\text { pendidikan. (Kode } \\
\text { TL-I-U2) }\end{array}$ & $\begin{array}{l}\text { Menambahkan, } \\
\text { menghapus dan } \\
\text { mereorganisasi alat } \\
\text { untuk memfasilitasi } \\
\text { presentasi konten; } \\
\text { penyimpanan, } \\
\text { komunikasi, } \\
\text { transmisi dan } \\
\text { pertukaran informasi; } \\
\text { dan akses terhadap } \\
\text { dan mencari } \\
\text { informasi berkualitas } \\
\text { (berdasarkan saran } \\
\text { dari kelompok } \\
\text { pendukung, rekan } \\
\text { kerja, siswa dan } \\
\text { orang lain). (Kode } \\
\text { TL-I-T1) }\end{array}$ \\
\hline Evaluasi & $\begin{array}{l}\text { Mengetahui keuntungan } \\
\text { menggunakan TIK untuk } \\
\text { memfasilitasi penilaian } \\
\text { yang efektif. (Kode TL-E- } \\
\text { F1) }\end{array}$ & $\begin{array}{l}\text { Menggunakan TIK untuk } \\
\text { menilai efektivitas dalam } \\
\text { hal penyimpanan, } \\
\text { komunikasi, transmisi dan } \\
\text { pertukaran informasi } \\
\text { dalam lingkungan } \\
\text { pendidikan. (Kode TL-E- } \\
\text { U1) }\end{array}$ & \begin{tabular}{lr} 
Menetapkan & kriteria \\
untuk & menilai \\
manfaat penggunaan \\
TIK \\
pengaturan dalam \\
pendidikan dalam hal \\
waktu, sumber daya, \\
akses \\
informasi terhadap \\
transmisi dan \\
penyimpanan konten. \\
\multicolumn{2}{l}{ Kode TL-E-T1) }
\end{tabular} \\
\hline
\end{tabular}


2. Level Pendalaman Pengetahuan (Knowledge Deepening)

\begin{tabular}{|c|c|c|c|}
\hline $\begin{array}{c}\text { Ruang } \\
\text { Lingku } \\
\quad p\end{array}$ & Familiarize & Utilize & Transform \\
\hline Desain & $\begin{array}{l}\text { 1. Mengelola penggunaan } \\
\text { TIK untuk penyimpanan, } \\
\text { komunikasi, transmisi dan } \\
\text { pertukaran informasi } \\
\text { dalam penyajian konten } \\
\text { pembelajaran. (Kode KD- } \\
\text { D-F1) } \\
\text { 2. Mengidentifikasi } \\
\text { hubungan antara aktifitas } \\
\text { pembelajaran, konten dan } \\
\text { TIK dalam pengaturan } \\
\text { pendidikan. Mengakui } \\
\text { bahwa TIK } \\
\text { memungkinkan praktik } \\
\text { pendidikan direplikasi } \\
\text { dalam berbagai setting } \\
\text { pendidikan. (Kode KD-D- } \\
\text { F2) }\end{array}$ & $\begin{array}{l}\text { 1. Mengatur penggunaan TIK untuk } \\
\text { presentasi konten dalam bentuk } \\
\text { multimedia dan hypermedia. } \\
\text { (Kode: KD-D-U1) } \\
\text { 2. Mengatur penggunaan TIK untuk } \\
\text { pemodelan dinamis (simulasi, } \\
\text { spreadsheet, microsoftworlds dan } \\
\text { sebagainya) untuk membangun } \\
\text { hubungan dinamis di antara } \\
\text { fenomena kompleks dan abstrak. } \\
\text { (Kode: KD-D-U2) }\end{array}$ & $\begin{array}{l}\text { Menambah } \\
\text { dan/atau } \\
\text { mengatur ulang } \\
\text { alat TIK yang } \\
\text { belum digunakan } \\
\text { berdasarkan } \\
\text { pengalaman } \\
\text { desain } \\
\text { sebelumnya. } \\
\text { (Kode: KD-D- } \\
\text { T1) }\end{array}$ \\
\hline $\begin{array}{l}\text { Implem } \\
\text { entasi }\end{array}$ & $\begin{array}{l}\text { 1. Memahami fungsi alat } \\
\text { TIK untuk meningkatkan } \\
\text { konstruksi pengetahuan } \\
\text { (aktif, otonom atau } \\
\text { kolaboratif). (Kode KD- } \\
\text { I-F1) } \\
\text { 2. Memahami peranan TIK } \\
\text { dalam membantu proses } \\
\text { konstruksi pengetahuan } \\
\text { dalam hal tingkat } \\
\text { partisipasi siswa, } \\
\text { perubahan konseptual } \\
\text { dan/atau kinerja akhir. } \\
\text { (Kode KD-I-F2) }\end{array}$ & $\begin{array}{l}\text { 1. Menggunakan berbagai aplikasi } \\
\text { dan/ atau alat TIK untuk mencapai } \\
\text { tujuan pembelajaran, diantaranya } \\
\text { untuk memperoleh gambaran suatu } \\
\text { fenomena kompleks, } \\
\text { mengorganisasi ilmu pengetahuan, } \\
\text { menggambarkan hubungan } \\
\text { dinamis antara fenomena } \\
\text { kompleks dan abstrak, dan } \\
\text { mengkontruksi ilmu pengetahuan } \\
\text { secara kolaboratif. (Kode KD-I- } \\
\text { U1) } \\
\text { Melaksanakan penilaian yang } \\
\text { memungkinkan TIK untuk } \\
\text { menunjukkan konstruksi } \\
\text { pengetahuan siswa sesuai dengan } \\
\text { tujuan pembelajaran. (Kode KD-I- } \\
\text { U2) } \\
\text { Memanfaatkan TIK untuk } \\
\text { memberikan umpan balik siswa } \\
\text { berdasarkan proses penilaian. } \\
\text { (Kode KD-I-U3) }\end{array}$ & $\begin{array}{l}\text { Mengusulkan } \\
\text { perubahan pada } \\
\text { setting } \\
\text { pendidikan yang } \\
\text { dimungkinkan } \\
\text { TIK berdasarkan } \\
\text { kriteria } \\
\text { perubahan yang } \\
\text { berkaitan dengan } \\
\text { estetika dan } \\
\text { aksesibilitas. } \\
\text { (Kode KD-I-T1) }\end{array}$ \\
\hline $\begin{array}{l}\text { Evaluas } \\
i\end{array}$ & 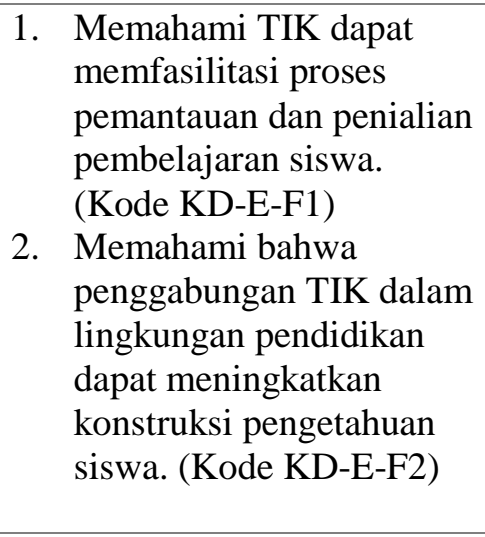 & $\begin{array}{l}\text { 1. Memanfaatkan informasi yang } \\
\text { disediakan oleh TIK untuk menilai } \\
\text { keefektifan praktek yang didukung } \\
\text { TIK dalam konstruksi } \\
\text { pengetahuan. (Kode KD-E-U1) } \\
\text { 2. Memantau manfaat penggunaan } \\
\text { TIK dalam lingkungan pendidikan } \\
\text { untuk membangun pengetahuan } \\
\text { kolaboratif, konstruksi } \\
\text { pembelajaran otonom dan } \\
\text { pembelajaran aktif. (Kode KD-E- } \\
\text { U2) }\end{array}$ & $\begin{array}{l}\text { Menetapkan } \\
\text { strategi untuk } \\
\text { menunjukkan } \\
\text { kontribusi } \\
\text { teknologi } \\
\text { terhadap } \\
\text { pengajaran dan } \\
\text { pembelajaran } \\
\text { siswa. (Kode } \\
\text { KD-E-T1) }\end{array}$ \\
\hline
\end{tabular}


3. Level Kreasi Pengetahuan (Knowledge Creation)

\begin{tabular}{|c|c|c|c|}
\hline $\begin{array}{c}\text { Ruang } \\
\text { Lingkup }\end{array}$ & Familiarize & Utilize & Transform \\
\hline Desain & $\begin{array}{l}\text { 1. Mengenali } \\
\text { pentingnya mencari } \\
\text { informasi terkini } \\
\text { tentang tren TIK } \\
\text { saat ini dalam } \\
\text { pendidikan. (Kode } \\
\text { KC-D-F1) } \\
\text { 2. Mengenali } \\
\text { pentingnya } \\
\text { memiliki sumber } \\
\text { daya dan batasan } \\
\text { yang jelas untuk } \\
\text { menggunakan TIK } \\
\text { sebelum merancang } \\
\text { pengaturan } \\
\text { pendidikan. (Kode } \\
\text { KC-D-F2) } \\
\text { Mengetahui } \\
\text { pentingnya konten, } \\
\text { kegiatan, dan } \\
\text { penilaian yang } \\
\text { koheren dalam } \\
\text { pengaturan } \\
\text { pendidikan yang } \\
\text { mendukung TIK. } \\
\text { (Kode KC-D-F3) }\end{array}$ & $\begin{array}{l}\text { 1. Mengusulkan } \\
\text { perubahan } \\
\text { signifikan dalam } \\
\text { setting pendidikan } \\
\text { lain untuk } \\
\text { mereplikasi konten, } \\
\text { kegiatan dan/atau } \\
\text { penilaian untuk } \\
\text { digabungkan dengan } \\
\text { TIK. (Kode: KC-D- } \\
\text { U1) } \\
\text { 2. Menyiapkan } \\
\text { lingkungan } \\
\text { pendidikan yang } \\
\text { tidak mungkin tanpa } \\
\text { penggunaan TIK } \\
\text { yang disengaja. } \\
\text { (Kode: KC-D-U2) } \\
\text { 3. Mengusulkan situasi } \\
\text { pendidikan } \\
\text { berdasarkan TIK } \\
\text { yang meningkatkan } \\
\text { pembelajaran } \\
\text { kolaboratif, } \\
\text { pemecahan masalah } \\
\text { yang nyata dan asli } \\
\text { dan materi yang } \\
\text { komprehensif dan } \\
\text { aplikatif. (Kode: } \\
\text { KC-D-U3) }\end{array}$ & $\begin{array}{l}\text { 1. Membuat perubahan } \\
\text { pada desain } \\
\text { pendidikan yang } \\
\text { diaktifkan dengan } \\
\text { TIK berdasarkan } \\
\text { kebutuhan siswa dan } \\
\text { karakteristik konten. } \\
\text { (Kode: KC-D-T1) } \\
\text { 2. Memperkaya struktur } \\
\text { pengaturan } \\
\text { pendidikan } \\
\text { berdasarkan potensi } \\
\text { karakteristik TIK. } \\
\text { (Kode: KC-D-T2) } \\
\text { 3. Mempertimbangkan } \\
\text { kemungkinan- } \\
\text { kemungkinan baru } \\
\text { yang ditawarkan oleh } \\
\text { TIK untuk } \\
\text { memperkaya } \\
\text { pendidikan } \\
\text { berdasarkan } \\
\text { karakteristik dan } \\
\text { potensi siswa untuk } \\
\text { belajar. (Kode: KC- } \\
\text { D-T3) }\end{array}$ \\
\hline Implementasi & 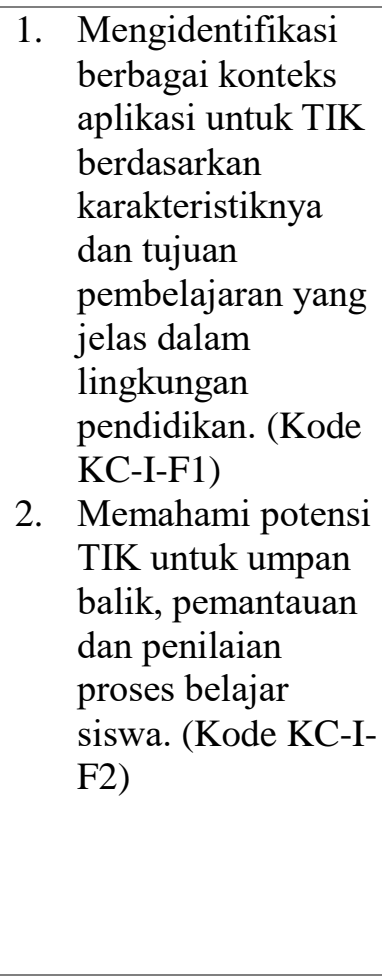 & 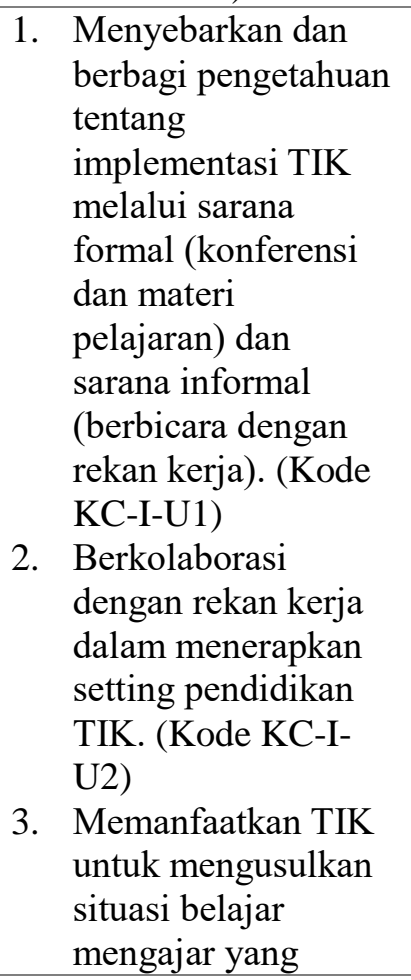 & 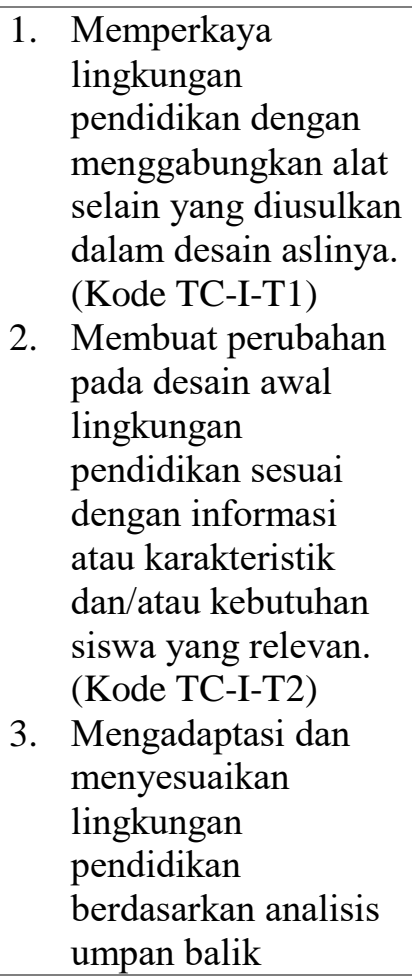 \\
\hline
\end{tabular}




\begin{tabular}{|c|c|c|c|}
\hline \multirow[t]{2}{*}{$\begin{array}{c}\text { Ruang } \\
\text { Lingkup }\end{array}$} & Familiarize & Utilize & Transform \\
\hline & & $\begin{array}{l}\text { melibatkan } \\
\text { pemecahan masalah } \\
\text { yang nyata dan asli. } \\
\text { (Kode KC-I-U3) } \\
\text { 4. Manfaatkan TIK } \\
\text { untuk } \\
\text { mempromosikan } \\
\text { pembelajaran } \\
\text { mendalam } \\
\text { (pemahaman dan } \\
\text { penerapan konten). } \\
\text { (Kode KC-I-U4) }\end{array}$ & $\begin{array}{l}\text { sistematis yang } \\
\text { diberikan oleh } \\
\text { implementasi TIK. } \\
\text { (Kode TC-I-T3) } \\
\text { 4. Mengusulkan } \\
\text { penggunaan TIK baru } \\
\text { untuk merancang, } \\
\text { menerapkan dan } \\
\text { menilai lingkungan } \\
\text { pendidikan untuk } \\
\text { meningkatkan } \\
\text { pembelajaran siswa } \\
\text { yang bermakna. } \\
\text { (Kode TC-I-T4) }\end{array}$ \\
\hline Evaluasi & 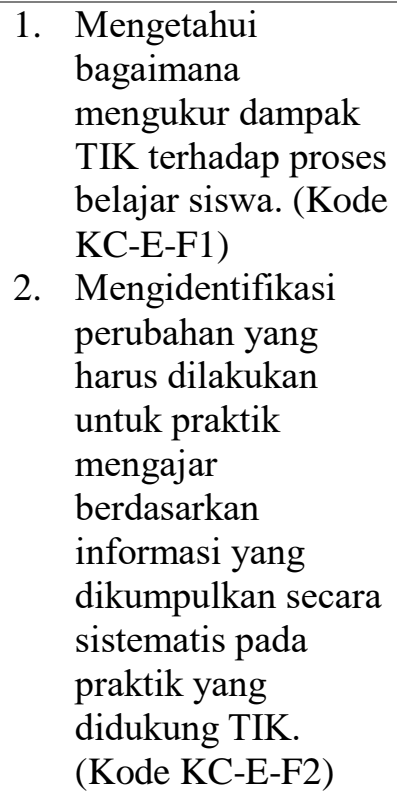 & 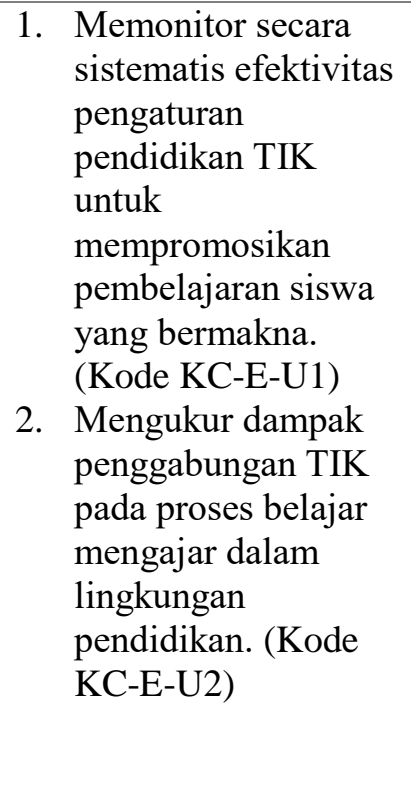 & $\begin{array}{l}\text { Mengkomunikasikan } \\
\text { strategi untuk memantau } \\
\text { dan menilai keefektifan } \\
\text { penggunaan TIK untuk } \\
\text { menigkatkan } \\
\text { pembelajaran siswa yang } \\
\text { bermakna. (Kode KC-E- } \\
\text { T1) }\end{array}$ \\
\hline
\end{tabular}

\section{Pembahasan}

Permendiknas Nomor 16 Tahun 2007 tentang Standar Kualifikasi Akademik dan Kompetensi Guru merupakan regulasi yang digunakan sebagai pijakan dalam menjabarkan kompetensi utuh guru. Kaitannya dengan kewajiban pemanfaatan TIK tercantum dalam Kompetensi Pedagogik untuk kepentingan penyelenggaraan kegiatan pengembangan yang mendidik, serta Kompetensi Profesional untuk berkomunikasi dan mengembangkan diri.

Peciuliauskiene \& Barkaukaite (2007) merumuskan definisi kompetensi TIK pendidikan sebagai kemampuan untuk menggunakan TIK dalam praktek pendidikan dan mengembangkan literasi komputer peserta didik serta kemampuan perencanaan, memanipulasi dan menganalisis proses aplikasi TIK. Senada dengan pendapat tersebut, Qing \& Qizhong (2012) menyatakan Kompetensi TIK adalah keterampilan apa yang dibutuhkan guru untuk menguasai pembelajaran menggunakan TIK, yaitu bagaimana seseorang menggunakan TIK untuk meningkatkan pembelajaran.

Untuk dapat memanfaatkan ICT dalam memperbaiki mutu pembelajaran, ada tiga hal yang harus diwujudkan yaitu (1) siswa dan guru harus memiliki akses kepada teknologi digital dan internet dalam kelas, sekolah, dan lembaga pendidikan guru, (2) harus tersedia materi yang berkualitas, bermakna, dan dukungan kultural bagi siswa dan guru, dan (3) guru harus memiliki pengetahuan dan 
ketrampilan dalam menggunakan alat-alat dan sumber-sumber digital. Sejalan dengan pesatnya perkembangan ICT, maka telah terjadi pergeseran pandangan tentang pembelajaran baik di kelas maupun di luar kelas (Wahyudin, 2010).

Kerangka kompetensi ini memberikan visi tentang pelatihan berkualitas yang dibutuhkan guru saat ini untuk menghadapi tantangan dalam mengajar di lingkungan masyarakat berpengetahuan dan informasi (knowledge and informastion society). Tentu saja ini sangat bermanfaat bagi para vendor diklat untuk dijadikan acuan dalam merancang pola diklat peningkatan kompetensi TIK yang sesuai dengan kebutuhan guru.

Tingkat adopsi TIK yang dikembangkan mengacu pada bagaimana guru memasukkan TIK ke dalam aktivitas kelas sehari-hari dan mengintegrasikannya ke dalam sistem simbol yang ada dalam setting pendidikan baik berupa bahasa lisan, tulisan, audiovisual, grafis, numerik atau estetika untuk menciptakan kondisi baru yang berkaitan dengan tujuan pendidikan. Adopsi terkait dengan pengetahuan guru dalam mengembangkan TIK, menggunakan instrumen yang dibuat dan perubahan yang dibuat guru untuk menyesuaikan dengan praktik pendidikannya. Tingkat adopsi TIK ini mulai dari bentuk yang paling sederhana hingga yang paling kompleks. Berkisar dari penggunaan TIK pada proses operasional di kelas, sampai ke tingkat lanjut di mana para guru dengan sengaja mengintegrasikan teknologi untuk menghasilkan pengalaman pendidikan yang akan sulit diterapkan tanpa menggunakan TIK.

Tujuan rencana diklat berdasarkan adopsi TIK harus mengembangkan serangkaian kompetensi dalam penggunaan teknologi dengan memprioritaskan keterampilan pada aspek perancangan (Design), penerapan (Implementation) dan penilaian (Assessment) kemampuan TIK pada ranah pendidikan. Ketiga aspek inilah yang menjadi ruang lingkup kompetensi TIK yang ditinjau dari dimensi pedagogik. Kompetensi dalam perancangan pendidikan (Design) mengacu pada perencanaan dan keterampilan mengorganisasi elemen yang mengarah pada konstruksi pendidikan untuk pembelajaran bermakna dan pendidikan komprehensif bagi siswa. Kompetensi dalam penerapan pendidikan (Implementation) berkaitan dengan keterampilan yang memfasilitasi perancangan dan perencanaan pendidikan dan kemudian tercermin dalam praktik pendidikan guru.

Terakhir, kompetensi untuk menilai pendidikan (Assessment) terkait dengan keterampilan yang memungkinkan guru mengevaluasi efektivitas untuk meningkatkan pembelajaran bermakna bagi siswa karena TIK dimasukkan ke dalam praktik pembelajaran.

Tingkat adopsi dalam hal kompetensi ini harus dipandang sebagai kegiatan yang dirancang oleh guru, dengan pemikiran tersebut, tidak mungkin mengaitkan satu tingkat kompetensi kepada masing-masing guru. Tingkat didasarkan pada bagaimana teknologi digunakan dalam praktik tertentu. Adapun tingkat adopsi yang dimaksud dalam dokumen ini terbagi kedalam tiga tingkatan, yaitu: (1) memperkenalkan (familiarize); (2) memanfaatkan (utilize); dan (3) mengubah (transform). Familiarize mengacu pada apa yang guru ketahui tentang teknologi dan penggunaannya (pengetahuan deklaratif). Utilize mengacu pada penggunaan praktik pendidikan sehari-hari yang melibatkan adopsi TIK (dengan kecenderungan prosedural). Terakhir, Transform berhubungan dengan perubahan adaptif terhadap praktik yang melibatkan penggunaan teknologi di kelas.

Sedangkan model adopsinya melalui adopsi teknologi bertahap yang meliputi tiga fase yakni Integrasi, Reorientasi dan Evolusi. Model ini telah disesuaikan dengan versi model penilaian Hooper dan Rieber (1995). Dimasukkan dua dimensi diatas (tingkat adopsi dan model adopsi) akan memperdalam analisis fase adopsi TIK dalam setting pendidikan dan memfasilitasi pemahaman yang lebih mendalam tentang apa yang terjadi dalam proses perancangan pendidikan. 
1. Level Integrasi

Tingkat adopsi ini melibatkan gagasan TIK sebagai alat yang mempermudah menyajikan konten, berkomunikasi dan menyampaikan informasi. Keputusan tentang penggunaan TIK dalam praktik pengajaran bergantung pada hal baru yang disediakan alat dalam hal menghemat waktu, biaya dan fleksibilitas.

Rancangan kegiatan berfokus pada peningkatan pengelolaan pendidikan sehari-hari. TIK digunakan untuk menginformasikan kegiatan yang akan datang, mengoptimalkan akses terhadap konten dan membuat pengelolaan sumber daya lebih fleksibel dalam ruang dan waktu. Tingkat ini mungkin melibatkan praktik yang diarahkan pada digitalisasi konten kelas, seperti beralih dari kertas ke digital. Guru menilai keefektifan integrasi TIK dalam praktiknya cenderung menekankan keterbatasan dan kontribusi dalam hal penghematan waktu, sumber daya dan akses terhadap sejumlah besar informasi. Salah satu contoh praktik yang bisa dikategorikan pada level ini adalah penggunaan multiple choice tests dengan menggunakan Learning Management System (LMS).

Secara umum, penggunaan TIK didasarkan pada karakteristik transmisi dan penyimpanan. TIK memfasilitasi komunikasi dan akses terhadap informasi yang dibutuhkan untuk mengajar. Transformasi berupa presentasi, penyimpanan, komunikasi, transmisi konten yang ditingkatkan.

2. Level Reorientasi

Pada tingkat ini, dalam kegiatan pendidikan tertentu guru menggunakan alat teknologi untuk mengatur praktik mengajar dengan partisipasi aktif siswa di sekitar kegiatan belajar-mengajar. TIK tidak lagi diwakili sebagai alat yang dapat dengan mudah, cepat dan murah memberi siswa akses ke sejumlah besar informasi, namun diadopsi sebagai alat yang memfasilitasi konstruksi pengetahuan berkat karakteristik spesifiknya: interaktivitas, formalisme, dinamisme, multimedia dan hypermedia.

Pada tingkat ini, pengajaran tidak bisa dilakukan tanpa menggunakan alat teknologi. Mengoptimalkan dan memanfaatkan karakteristik tersebut memungkinkan TIK untuk digunakan oleh siswa dan guru untuk merencanakan, mengatur dan memandu proses intramental (kemampuan seseorang untuk menyelesaikan tugastugas atau memecahkan berbagai masalah secara mandiri) dan intermental (berkolaborasi dengan teman sebaya yang lebih kompeten) yang terlibat dalam konstruksi pengetahuan.

Salah satu contoh latihan di level ini adalah blogging kolaboratif untuk membantu pemahaman topik yang dibahas di kelas. Guru menggunakan alat terpadu ini di kelas dan meminta siswa untuk menulis tentang pemahaman mereka tentang isinya. Namun, proses penulisannya diperkaya dengan karakteristik multimedia dan hypermedia TIK. Hal ini dicapai ketika guru meminta siswa untuk menulis blog berdasarkan pencarian dan sumber online mereka sendiri, sementara juga berbagi sudut pandang dan sumber daya digital.

3. Level Evolusi

Pada tingkat ini, jelas bahwa TIK menciptakan lingkungan yang melibatkan sistem semiotik yang dikenal dan mendorong kapasitas manusia untuk mewakili, memproses, mentransmisikan dan berbagi informasi ke dalam lingkungan baru. Dari perspektif ini, guru menggunakan potensi tersebut untuk menjembatani hubungan antara siswa dan konten pembelajaran, serta interaksi dan pertukaran antara guru dan siswa dan kalangan siswa, kolega, institusi dan kelompok penelitian.

Guru memanfaatkan TIK dengan baik dengan cara menunjukkan hubungan yang koheren antara keseluruhan isi materi, tujuan dan aktivitas pembelajaran, kegiatan penilaian dan berbagai alat teknologi untuk 
menjebatani (memfasilitasi, meningkatkan, meningkatkan dan mengembangkan) pencapaian tujuan pendidikan. Ini dikombinasikan dengan serangkaian saran dan panduan tentang bagaimana menggunakan alat ini untuk mengembangkan kegiatan belajar mengajar. Guru dapat berkolaborasi dan berbagi kemajuan dengan rekan kerja sambil membantu mereka merangkul beberapa alat teknologi itu sendiri.

\section{PENUTUP}

Kompetensi pedagogik sebagai salah satu standar dari guru profesional merupakan kompetensi yang wajib dimiliki seorang guru yang dibangun melalui pengetahuan mendalam tentang proses dan praktik pengajaran dan pembelajaran. Melibatkan masalah pembelajaran siswa, manajemen kelas, pengembangan dan pelaksanaan rencana pelajaran dan evaluasi siswa, teknik atau metode yang akan digunakan di kelas dan pemanfaatan TIK dalam penyelenggaraan kegiatan pembelajaran.

Peningkatan kompetensi guru yang berkaitan dengan pemanfaatan Teknologi Informasi dan Komunikasi (TIK) menjadi suatu kebutuhan mendesak untuk menjadi seorang guru profesional di abad 21 . Didukung oleh kebijakan pengintegrasian mata pelajaran TIK dalam Kurikulum 2013 pada semua mata pelajaran semakin menekankan kewajiban penguasaan TIK oleh semua guru, bukan hanya guru TIK.

Dengan demikian, diperlukan pemetaan kompetensi TIK guru dari dimensi pedagogik yang dapat menggambarkan kompetensi TIK utuh yang harus dikuasi oleh seorang guru. Selama ini belum dikembangkan standar kompetensi TIK guru, sehingga lembaga pendidikan dan pelatihan (diklat) merancang konten TIK masing-masing sesuai dengan analisis kebutuhan (training needs assessment).

Studi pendahuluan pada penelitian ini telah menghasilkan peta kompetensi TIK yang akan berguna sebagai rujukan perancangan diklat peningkatan kompetensi TIK guru atau Program Peningkatan
Keprofesian Berkelanjutan (PKB). Kompetensi TIK guru dipetakan dalam 3 (tiga) level kompetensi secara berjenjang.

Level 1. Literasi Teknologi (technology literacy); terkait dengan integrasikan teknologi, peralatan (tools), dan konten digital ke dalam praktik pedagogi di kelas, kelompok dan kegiatan individu siswa untuk mendukung proses pembelajaran

Level 2. Kreasi Pengetahuan (knowledge creation); terkait dengan pemecahan masalah yang kompleks (Complex Problem Solving). TIK tidak lagi diwakili sebagai alat yang dapat dengan mudah, cepat dan murah memberi siswa akses ke sejumlah besar informasi, namun diadopsi sebagai alat yang memfasilitasi konstruksi pengetahuan. Guru dalam hal ini menerapkan pendekatan pembelajaran berbasis proyek dan berbasis masalah kolaboratif (collaborative problem) dimana siswa mengeksplorasi subjek secara mendalam dan menggunakan pengetahuan mereka untuk menyelesaikan masalah kompleks, isu-isu, dan pertanyaan sehari-hari dengan mengoptimalkan TIK.

Level 3. Kreasi Pengetahuan (knowledge creation); terkait dengan manajemen diri (Self Management). Siswa bekerja dalam komunitas belajar untuk menciptakan produk-produk yang dibangun dari pengetahuan dan keterampilan mereka sendiri. Peran guru dalam pendekatan ini adalah secara eksplisit memodelkan proses belajar dan menciptakan situasi di mana siswa menerapkan keterampilan kognitif dan membimbing mereka dalam mencapai kemahiran. Guru juga berkolaborasi dengan rekan kerja dalam menerapkan setting pendidikan yang diaktifkan dengan TIK.

Peningkatan kompetensi guru untuk mengintegrasikan TIK dalam pembelajaran mutlak diperlukan untuk mewujudkan guru profesional yang memiliki ilmu pengetahuan dan teknologi yang mumpuni, sehingga diharapkan mampu membangun dan mendidik generasi emas Indonesia di Abad 21.

Studi pendahuluan pada penelitian ini masih banyak memiliki keterbatasan, peta kompetensi TIK guru dan deskripsi 
kompetensi yang dihasilkan memerlukan kajian lebih lanjut dan validasi dari para pakar (expert judgment). Dengan demikian, penelitian lanjutan sangat diperlukan untuk menghasilkan peta kompetensi tervalidasi, sebelum dapat dikembangkan menjadi rancangan diklat dan sebagai acuan dalam pengembangan modul diklat.

\section{UCAPAN TERIMA KASIH}

Peneliti menghaturkan terimakasih kepada Pimpinan dan Staf PPPPTK Pertanian khususnya di Bidang Program atas akes data yang diberikan, serta Pimpinan Biro Perencanaan dan Kerjasana Luar Negeri (BPKLN) Kementerian Pendidikan dan Kebudayaan yang telah berkenan memberikan biaya pendidikan melalui Beasiswa Unggulan sebagai Pegawai Kemdikbud.

\section{DAFTAR PUSTAKA}

Akker, J. van den et. a. (1999). Design Approaches and Tools in Education and Training. Kluwer Academic Publishers.

http://doi.org/10.1007/978-94-0114255-7

Hooper, S., \& Rieber, L. P. (1995). Teaching with technology. In A. C. Ornstein (Ed.), Teaching: Theory into practice. Needham Heights, MA: Allyn and Bacon.

Kemendikbud. (2015a). Pedoman Pelaksanaan Uji Kompetensi Guru. Pedoman Uji Kompetensi Guru.

Kemendikbud. (2015b). Pedoman Penyusunan Modul Diklat. Direktorat Jenderal Guru dan Tenaga Kependidikan, Kemdikbud.

Kemendikbud. (2017). Pedoman Umum Program Pengembangan Keprofesian Berkelanjutan. Jakarta: Direktorat Jenderal Guru dan Tenaga Kependidikan, Kemdikbud.

Kristiawan, M. dkk. (2017). Manajemen Pendidikan. Yogyakarta: Deepublish.

Lampiran Peraturan Presiden RI No. 32 Tahun 2011 Masterplan Percepatan dan Perluasan Pembangunan Ekonomi Indonesia 2011 - 2025. Indonesia.

Maulipaksi, D. (2016). 7 Provinsi Raih
Nilai Terbaik Uji Kompetensi Guru 2015. Retrieved January 3, 2018, from https://www.kemdikbud.go.id/

Mulyasa, E. (2013). Menjadi Guru Profesional:

Pembelajaran Kreatif dan Menyenangkan. Bandung: PT. Remaja Rosdakarya.

Murti, K. E. (2015). Pendidikan abad 21 dan aplikasinya dalam pembelajaran di SMK. (2009). Retrieved from http://www.p4tksbjogja.com/images/artikel/Pendidikan_ Abad_21_dan_Aplikasinya_dalam_P embelajaran_di_SMK_-_Kuntari.pdf

Peciuliauskiene, Palmira., \& Barkauskaite, Marija. (2007). Would-Be Teachers' Competence in Applying ICT: Exposition and Preconditions for Development. Informatics in Education, IV, No. 2, 397-410.

Peraturan Kepala BPPK Nomor PER003/PP/2009.

Peraturan Kepala LAN Nomor 5 tahun 2009 (2009).

Peraturan Kepala Lembaga Administrasi Negara (LAN) Nomor 1 Tahun 2006 (2006).

Qing, Z., \& Qizhong, O. (2012). Study on cultivation of teachers' ICT ability. In 7th Nternational Conference on Computer Science \& Education (ICCSE).

Rajsekhar. (2013). The Role of Information and Communication Technology in Teacher in India: A Study.

Richey, R. C. \& Klein, J. D. (2007). Design and Development Research. Lawrence Erlbaum Associates, Inc.

UU Nomor 14. (2005). Undang-undang Republik Indonesia Nomor 14 Tahun 2005 tentang Guru dan Dosen. Produk Hukum, 2.

Wahyudin, D. (2010). Model Pembelajaran ICARE Pada Mata Pelajaran TIK di SMP. Jurnal Penelitian Kependidikan, Vol. 11, Nomor 1.

Wahyudin, D. (2016). Manajemen Kurikulum dalam Pendidikan Profesi Guru (Studi Kasus di Universitas Pendidikan Indonesia. Jurnal 
Kependidikan, Vol. 46, Nomor, 259270.

Wahyudin, D. (2017). Curriculum Development and Teaching

Philosophy. Germany: Lambert Academic Publishing Saarbrucken. 